\title{
SEROEPIDEMIOLOGY OF TOXOPLASMOSIS IN WOMEN OF CHILDBEARING AGE FROM A MARGINAL COMMUNITY OF MARACAIBO, VENEZUELA
}

\author{
Odelis DIAZ-SUÁREZ \& Jesus ESTEVEZ
}

\begin{abstract}
SUMMARY
The aim of this study was to determine the prevalence of anti-T. gondii total and IgM antibodies in women of childbearing age. One hundred serum samples of women were studied with age range from 11 to 45 years old. Samples were chosen by random. The determination of total antibodies was carried out through the indirect hemagglutination technique and IgM antibodies by ELISA's technique. The statistical analysis was carried out through the Chi square and the Spearman correlation tests. The theoretical estimated incidence of congenital toxoplasmosis was calculated, according to the annual increment of antibody prevalence among the age groups. The overall prevalence of toxoplasmosis was 33\%, while only six individuals (18.2\%) were positive to IgM. The highest prevalence was observed in the 11-35 year-old age group. The theoretical estimated incidence was 1.5 for 100 pregnancies in women of 21-25 year-old group; it decreased until $0.1 \%$ in the $41-45$ year-old age group. The findings show a high prevalence of toxoplasmosis in this community with a high infection risk in women of the studied age group and the high cat population observed, suggesting that the transmission way by contaminated soils may play a main role in the spreading of toxoplasmosis in this community.
\end{abstract}

KEYWORDS: Toxoplasmosis; Seroprevalence; Women; Age; Marginal.

\section{INTRODUCTION}

Toxoplasmosis is the most common parasitic infection in the world. The clinical infection is often asymptomatic in healthy people, but it can cause severe complications in immunosuppressed subjects ${ }^{4,9}$. The infection of pregnants frequently is an asymptomatic or mild disease, difficulting diagnosis and can produce deleterious effects in the fetus. The early detection of this infection is the high importance to prevent those effects ${ }^{27,30}$. In spite of, in several developing countries, the early detection and prevention programs have been implemented, only it is known the incidence of toxoplasmosis vertical transmission throughout the frequency of tetarogenic effects in the population of newbirth ${ }^{27}$.

T. gondii infection is widely spread in Latin America, mainly in tropical areas, where shows prevalence range of $65 \%$ in the population ${ }^{15,28}$. High prevalence has been reported in Chile ${ }^{10,28}$, Brazil $^{5,19}$, Ecuador ${ }^{17}$, Panamá $^{15,31}$, Costa Rica ${ }^{18}$, Mexico $^{34}, \mathrm{Cuba}^{24}$ and Venezuela ${ }^{8,12,16,23,25,29}$.

In reproductive age women have been observed prevalence between four to $93 \%$ in some countries s $^{1,7,11,14,25,27}$.

Some studies have determined the toxoplasmosis prevalence in several urban groups and communities from Venezuela as follow: 31.8$61 \%$ in pregnants ${ }^{16,23}, 41.8-53.5 \%$ in individuals between 0 to 60 years old $^{8,29}, 57.6 \%$ and $66.7 \%$ in children under 15 years old ${ }^{8,33}$, and $36.6 \%$ in subject between eight months to 76 years old in marginal areas ${ }^{12}$. In rural areas, $39 \%^{29}$ in 18 to 20 years old soldiers, and $49.3 \%$ individuals between 0 to 60 years old ${ }^{23}$.

The information about T. gondii infection and geographical distribution in Venezuela is fractioned, since most studies have been based on non-representative hospital samples of the population.

The aim of this study was to determine the seroprevalence of $T$. gondii antibodies in childbearing age women of a suburban marginal community from Maracaibo, State Zulia, Venezuela, who constitute a high risk group for congenital toxoplasmosis because the community has a high cat population together with a high annual newbirths rate.

\section{PATIENT AND METHODS}

Studied area and population: Puerto Caballo is a coastal marginal community, located at the north of Estado Zulia, Venezuela. It has two (waist management and electricity) of the basic services. The economical level of the population is very low.

Most of houses of this town are distributed lineally, one beside the other and in front of the main sandy street, they do not present dividing 
DIAZ-SUÁREZ, O. \& ESTEVEZ, J. - Seroepidemiology of toxoplasmosis in woman of childbearing age from a marginal community of Maracaibo, Venezuela. Rev. Inst. Med. trop. S. Paulo, 51(1): 13-17, 2009.

fences and are built with walls of bricks, thin roofs and, cement or sand floors. The number of individuals living in each house varies from five to 16 .

The cat population is high, they stroll freely around the community, visiting numerous houses and depositing their excrements around the houses and inside them.

The community shows a poor sanitary condition, lacking of an appropriate effectual excretes system. The potable water is often obtained through cistern trucks and it is stored in uncover containers.

Most of their inhabitants live off fishing. Their consumption of meats is scarce, and the meat they eat is not well cooked.

The total population of Puerto Caballo, at the moment of this study, was formed by 1145 individuals of both sexes with an age range between three months to 70 years old. The sample belonged to 100 women in childbearing age (12 to 49 years old), who were chosen by random.

The women consent or their representatives were obtained, before to their inclusion in the study. A survey to obtain basic information such as: age, occupation, number and time between pregnancies, sanitary and socioeconomic conditions, condition of habitat and nutrition habits. This investigation was approved by the Ethical Committee of Zulia University and, it was designed following the parameters of the Declaration of Helsinki.

Methods: The blood samples were obtained by veined punction and centrifuged 2500 r.p.m by five min. The recollected sera were frozen at $-20{ }^{\circ} \mathrm{C}$ until their analyses. The total antibodies were determined by the indirect hemagglutination technique (Toxotest HAI Wiener Lab), and the IgM antibodies through the ELISA's technique (ETI-TOXOK-M. DiaSorin S.R.L). A reactive dilution above 1:64 was considered as positive to HAI.

Statistical Analysis: Data were expressed in distribution of frequencies. It was carried out by Chi-square test and the Fischer exact analysis, as it corresponded, to determine significant differences among the studied groups. It was performed Spearman correlation analysis to define relationship among the studied variables. It is taken $95 \%$ as confidence index. It was considered significant all probability lesser than $0.05(\mathrm{p}<0.05)$.

The accumulated prevalence, increased seropositivity percentage, annual increment of the seropositive percentage, increment of percentage for nine months and, theoretical incidence estimated of congenital toxoplasmosis were calculated based on the mathematical methods used by PUNDA-POLIC et al. ${ }^{27}$ for data with heterogeneous age groups. To estimate congenital toxoplasmosis incidence was used the estimated Latin-American incidence mean (10\%) of toxoplasmosis calculated of several studies $5,8,10,12,16,17,18,23,24,29,33,34$.

\section{RESULTS}

Table 1 represents the prevalence of anti- $T$. gondii total antibodies and the theoretical annual estimated incidence of congenital toxoplasmosis in childbearing age women from the studied groups. The overall prevalence was $33.0 \%$, being observed picks of prevalence in the age groups of $11-15$ (45\%), 21-25 (53.8\%) and 31-35 years old (60.0). The highest annual increases were $9.1 \%$ and $4.8 \%$ in $11-15$ and $21-25$ year-old groups, respectively. The highest risk of theoretical estimate congenital toxoplasmosis was 2.7 for 100 pregnancies in $11-15$ year-old group. The theoretical incidence of congenital toxoplasmosis decreased gradually of $2.7 \%$ for the $11-15$ years old group to $0.1 \%$ for the groups of 40 years old. The overall theoretical estimate incidence of congenital toxoplasmosis was 0.8 for 100 pregnancies.

Distribution of anti-T. gondii total and IgM antibodies is shown in Table 2. The overall positive percentage was $33.0 \%$ (33/100) for total antibodies and $18.2 \%$ (6/33) for IgM antibodies. The highest positive percentages of total antibodies were observed in 31-35 years old women (60.0\%), while to IgM antibodies the highest incidence was determined in 41-45 years old women. The geometric mean of total antibody titers (TGM) was 302.8, being higher in the 11-15 year-old age group. The prevalence of 31-35 years old group shows a statistical difference regarding 16-20 $(\mathrm{p}<0.05)$ and $36-40(\mathrm{p}<0.01)$ year-old groups. Furthermore, the $21-25$ and $36-40$ years old groups were different $(\mathrm{p}<0.05)$.

Table 1

Prevalence of anti-T. gondii total antibodies and estimation of theorical annual incidence of congenital toxoplasmosis by age group in women of childbearing age

\begin{tabular}{|c|c|c|c|c|c|c|c|}
\hline Age groups & $\begin{array}{c}\text { Total Antibodies } \\
\text { Positives/ } \\
\text { Examined }\end{array}$ & $\%$ & $\begin{array}{l}\text { Accumulate } \\
\text { Prevalence }\end{array}$ & $\begin{array}{l}\text { Increment of \% } \\
\text { seropositives }\end{array}$ & $\begin{array}{l}\text { Annual increment I } \\
\text { of } \% \text { seropositives }\end{array}$ & $\begin{array}{l}\text { rement of \% to } \\
9 \text { months }\end{array}$ & $\begin{array}{l}\text { Theorical } \\
\text { incidence of } \\
\text { congenital } \\
\text { toxoplasmosis }\end{array}$ \\
\hline $11-15$ & $5 / 11$ & 45.5 & 45.5 & 45.5 & 9.1 & 6.8 & 2.7 \\
\hline $16-20$ & $3 / 17$ & 17.6 & 55.1 & 9.6 & 1.9 & 1.4 & 0.6 \\
\hline $21-25$ & $7 / 13$ & 53.8 & 79.3 & 24.2 & 4.8 & 3.6 & 1.5 \\
\hline $26-30$ & $6 / 22$ & 27.3 & 84.9 & 5.7 & 1.1 & 0.8 & 0.3 \\
\hline $31-35$ & $6 / 10$ & 60.0 & 94.0 & 9.0 & 1.8 & 1.4 & 0.5 \\
\hline $36-40$ & $1 / 14$ & 7.1 & 94.4 & 0.4 & 0.1 & 0.1 & 0.0 \\
\hline $41-45$ & $5 / 13$ & 38.5 & 96.6 & 2.2 & 0.3 & 0.3 & 0.1 \\
\hline
\end{tabular}


Table 2

Distribution of total and IgM antibodies against $T$. gondii by age group

\begin{tabular}{|c|c|c|c|c|c|}
\hline \multirow{2}{*}{$\begin{array}{l}\text { Age Groups } \\
\text { (years old) }\end{array}$} & \multicolumn{2}{|c|}{ Total Antibodies } & \multicolumn{2}{|c|}{$\operatorname{IgM}$} & \multirow{2}{*}{ TGM } \\
\hline & Positives/Examined & $\%$ & Positives/Examined & $\%$ & \\
\hline $11-15$ & $5 / 11$ & 45.5 & $0 / 5$ & 0.0 & 2352.5 \\
\hline $16-20$ & $3 / 17$ & 17.6 & $0 / 3$ & 0.0 & 256.0 \\
\hline $21-25$ & $7 / 13^{\mathrm{b}}$ & 53.8 & $1 / 7$ & 14.3 & 231.9 \\
\hline $26-30$ & $6 / 22$ & 27.3 & $0 / 6$ & 0.0 & 228.1 \\
\hline $31-35$ & $6 / 10^{\mathrm{a}}$ & 60.0 & $2 / 6$ & 33.3 & 287.4 \\
\hline $36-40$ & $1 / 14$ & 7.1 & $0 / 1$ & 0.0 & 64.0 \\
\hline $41-45$ & $5 / 13$ & 38.5 & $3 / 5$ & 60.2 & 128.0 \\
\hline Total & $33 / 100$ & 33.3 & $6 / 33$ & 18.2 & 302.8 \\
\hline
\end{tabular}

${ }^{a}$ Statistical difference regarding $16-20(\mathrm{p}<0.05)$ and $36-40(\mathrm{p}<0.01)$ age groups; ${ }^{\mathrm{b}}$ Statistical difference regarding $36-40(\mathrm{p}<0.05)$ age group.

Table 3

Distribution of anti-T. gondii titers in the studied women

\begin{tabular}{lcc}
\hline $\begin{array}{l}\text { Titers } \\
\text { Total antibodies }\end{array}$ & $\mathrm{n}$ & $\%$ \\
\hline $1: 64$ & 7 & 21.2 \\
$1: 128$ & 9 & 27.3 \\
$1: 256$ & 6 & 18.1 \\
$1: 512$ & 2 & 6.1 \\
$1: 1024$ & 2 & 6.1 \\
$1: 2048$ & 3 & 9.1 \\
$1: 4096$ & 4 & 12.1 \\
\hline Total & 33 & 100.0 \\
\hline
\end{tabular}

The distribution of total antibody titers can be observed in Table 3. The highest percentage was $(72.2 \%, 24 / 33)$ of low titers $(1: 64-1: 512)$, while the lowest percentage was $(27.8 \%, 9 / 33)$ of high titers $(1: 1024$ $1: 4096)$.

\section{DISCUSSION}

Obtained results indicate that the $T$. gondii infection is endemic in the studied population. Several studies suggest that the primary infection occurs in early stages of life and it is strongly influenced by close contact with oocyst in feces of infected cats which contaminate soils. The overall prevalence of antibodies was lower than the ones reported in previous studies in urban ${ }^{8,29}$, and rural populations ${ }^{29}$, and similar to the ones observed in other marginal communities from Estado Zulia ${ }^{12}$.

The seroprevalence was lower than the ones reported in other countries such as: Senegal $(40.3 \%)^{11}$, Turkey $(39.6 \%)^{14}$, Bangladesh $(38.5 \%)^{1}$, Croatia $(38.1 \%)^{27}$ and, Yugoslavia $(57-93 \%)^{7}$, higher than the one observed in India $(7.72 \%)^{25}$, and similar to the one reported in Mexico $(33.4 \%)^{34}$.
The high percentage $(66.7 \%)$ of non-infected women observed in childbearing age demonstrated that they are in a high risk condition to acquire this infection during the pregnancy, whose consequences in the fetus are known ${ }^{2,3,27}$. Early studies suggest a progressive increase of prevalence observed in women in the first decades of life, it may indicate that they are often infected when reach the childbearing age ${ }^{27,30}$. The transmission of $T$. gondii infection is only possible to the fetus when women are infected during the pregnancy; the risk of fetal infection should be low in the rest of female population. On the contrary, the present findings determined that $54.5 \%$ of the younger women of childbearing age are negative to anti-Toxoplasma antibody test, showing estimated risk index of 2.7 to 100 pregnancies.

The highest prevalence (total antibodies) and incidence (IgM) demonstrated in the 11-15, 21-25, and 31-35 years-old groups and the statistical differences observed between these groups and the 16-20 and 36-40 years old groups, suggests intermittent periods of Toxoplasma infection, with average periods of five years where the no-infected population seems to have a higher susceptibility to the parasite. Since the pregnancy has been considered an immunosuppressant condition ${ }^{25,35}$, this stage may allow a high infection risk for some pathologies. The fact that these susceptible periods match to the media time between pregnancies $(4.43 \pm 2.15$ years $)$ in the studied women may give explanation to the observed results. The finding of highest titers in the age groups with the highest prevalence seems to corroborate this fact, a close and lasting contact with $T$. gondii antigen join to periods of high susceptibility may explain $i^{25}$. Further studies are required to clear these results.

In spite of the aforesaid picks of prevalence, the high titer geometric mean (TGM) of 11-15 years old group and an inverse relationship between the age and TGM suggest that the women of the studied community were infected in the first decades of life, which is in agreement with previous studies ${ }^{1,11,13,25}$. The TGM of 16-35 years old group is very near to overall TGM (302.8), what could correspond to persistent circulation of Toxoplasma antigen in the population. It is probable due to the high cat population, which contaminate the soils inside and outside of housing, because people are in close contact with the oocysts for long time. The accumulated risk of suffering toxoplasmosis during pregnancy 


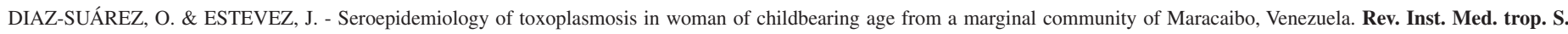
Paulo, 51(1): 13-17, 2009.

determined in the studied women, increases the possibility that their fetus may present congenital toxoplasmosis. Some studies reported highest risk in the products of women above 30 years old, while the lowest incidence would be seen in newborns of women under 36 years old $^{25}$. The estimated risk of acquired toxoplasmosis to pregnant and fetus determined in the present study points out a similar epidemiologic behavior. The percentage of high titers $(27.2 \%)$ may suggest early or active disease, or a high reinfection rate. Development of more sensitive and discriminative techniques are needed to clear the immunologic status of individuals infected with $T$. gondii. At the present time, IgM antibody is not considered as a reliable marker of early infection, since several studies have demonstrated persistence of IgM antibodies for long time ${ }^{22,32}$.

Among several transmission ways described for $T$. gondii, infection by contaminated soils, eat raw meat, or transplacental ${ }^{4,9}$, the first one seems to play a main role in the spreading of infection into the studied community. The high percentage of intestinal parasites (84.6\%), mainly geohelminths, determined by a previous study in this community (unpublished data), it is a strong evidence of prolonged and close contact with contaminated soils, since helminths and $T$. gondii oocysts follow the same oral-fecal infection route. The ingestion of raw meat do not seem to play any role in the toxoplasmosis transmission, once diet of the studied community contains few well-cooked meat.

The social-economic status of studied women is very low and the prevalence of $T$. gondii infection is high, and seems to support the inverse relationship between economic condition and toxoplasmosis reported by other studies ${ }^{1,34}$.

The domestic and wild cats have been considered the main source of Toxoplasma oocysts, although the main risk factor is the relation between the cat population and the size of their areas to defecate. The populations of rural cats are often higher than the urban cat ones, but the urban cats defecate in limited areas: sandbanks inside the housing, small gardens and surrounding of houses. In these areas, the concentration of Toxoplasma oocysts may be very high, therefore the infection risk also could be increased in humans, while rural cats have wide areas to defecate and the oocyst concentration of these areas is lower than in the previous case, being the infection of low risk in the rural human population.

The use of uncovered recipients to store water may lead to the spreading of the infection by water contamination with cat feces. Indeed, the water has been implied as a way of epidemic and endemic transmission in places where it is stored in open containers ${ }^{6,15}$. Therefore, the infection risk may be increased when the population lack potable water and this is stored in inadequate containers.

The world incidence of $T$. gondii primary infection acquired during pregnancy varies widely with a range between $1 / 100$ to $1 / 3000$ pregnancies ${ }^{20,26,27}$. In Venezuela, previous studies are not available about the toxoplasmosis incidence; this study estimated the theoretical incidence of congenital toxoplasmosis by the increment of anti-T. gondii antibodies in the studied population. According to the obtained results, it is known that the frequency of primary infection into the age groups may provide an adequate estimation of the number of pregnancies under risk in this population. These results point out to the adolescent and young adult women as the most vulnerable groups for the acquisition of primary toxoplasmosis during the pregnancy. This fact has been reported previously $^{20}$. It would be enlightened to compare the toxoplasmosis incidence forecast with data based on the conversion of IgG levels, frequency and persistence of anti-T.gondii $\operatorname{IgM}$ antibodies and, the $\mathrm{IgG}$ avidity test $\mathrm{t}^{21}$. The last test, although routine in Europe and U.S.A. is uncommon in Latin America, and discriminates between early and chronic Toxoplasma infection.

The findings obtained in the present study emphasize the need to establish preventive programs against $T$. gondii infection, since only prospective studies can provide real data about the maternal incidence even the frequency of congenital toxoplasmosis. Although toxoplasmosis can be an avoidable disease it justifies the call for implementation of such programs.

\section{RESUMO}

\section{Soroepidemiologia da toxoplasmose em mulheres em idade fértil em comunidade marginal de Maracaibo, Venezuela}

A finalidade do presente estudo foi determinar a prevalência de anticorpos totais e IgM anti-Toxoplasma gondii, em mulheres em idade fértil. Estudaram-se 100 amostras de soro de mulheres com idade entre 11 e 45 anos. Amostras foram escolhidas ao acaso. A determinação de anticorpos totais foi realizada com a técnica de hemaglutinação indireta e a determinação de anticorpos IgM, pela técnica de ELISA. A análise estatística foi realizada usando a prova do Chi quadrado e a correlação de Spearman. A incidência teórica estimada da toxoplasmose congênita foi calculada de acordo com o incremento anual da prevalência de anticorpos entre os diversos grupos de acordo com a idade. A prevalência geral de toxoplasmose foi de $33 \%$, enquanto somente seis pacientes $(18,2 \%)$ foram positivos para IgM. A prevalência maior foi observada no grupo de 11-35 anos de idade. A incidência teórica estimada foi de 1,5 por 100 mulheres grávidas no grupo de 21-25 anos de idade; diminuiu até $0,1 \%$ no grupo de 41-45 anos de idade. Os resultados obtidos refletem alta prevalência de toxoplasmose nesta comunidade, além de alto risco de infecção nas mulheres no grupo de idade estudado, sugerindo-se que a transmissão através de fezes de gato, pode ter papel preponderante.

\section{ACKNOWLEDGEMENTS}

Special thanks to Lic. Thais Villasmil, Translator.

\section{REFERENCES}

1. ASHRAFUNNESSA; KHATUNS, S.; ISLAM, M.N. \& HUQ, T. - Seroprevalence of Toxoplasma antibodies among the antenatal population in Bangladesh. J. Obstet. Gynecol. Res., 24: 115-119, 1998.

2. ASPOCK, H. \& POLLAK, A. - Prevention of prenatal toxoplasmosis by serological screening of pregnant women in Austria. Scand. J. infect. Dis. Suppl., 84: 32-37, 1992.

3. AULT, K.A. \& FARO, S. - Viruses, bacteria and protozoan in pregnancy: a sample of each. Clin. Obstetric. Gynecol., 36: 878-885, 1993.

4. ATIAS, A. - Parasitología clínica. Santiago, Editorial Publicaciones Técnicas Mediterráneo, 1991. p. 270-283.

5. BARUZZI, R.G. - Contribution to the study of toxoplasmosis epidemiology. Serologic survey among the indians of the upper Xingu River, Central Brazil. Rev. Inst. Med. trop. S. Paulo, 12: 93-104, 1971. 

Paulo, 51(1): 13-17, 2009.

6. BENENSON, M.W.; TAKAFUJI, E.T.; LEMON, S.M.; GREENUP, R.L. \& SULZER, A.J. - Oocysts transmitted toxoplasmosis associated with ingestion of contamined water. New Engl. J. Med., 307: 666-669, 1982.

7. BOBIC, B.; JEVREMOVIC, I.; MARINKOVIC, J.; SIBALIC, D. \& DJUERKOVICDJAKOVIC, O. - Risk factors for Toxoplasma infection in a reproductive age female population in the area of Belgrade, Yugoslavia. Europ. J. Epidem., 14: 605-610, 1998

8. BONFANTE-GARRIDO, R.; DE ALVAREZ, N.M.; DE ANZOLA, N.H. et al. Toxoplasmosis en pacientes de 14 estados de Venezuela. Bol. Ofic. sanit. Panamer., 96: $502-510,1984$

9. BOTERO. D. \& RESTREPO, M. - Parasitosis humanas. Medellín, Corporación para Investigaciones Biológicas, 1998. p. 252-720.

10. CONTRERAS, M.; SCHENONE, H.; SALINAS, P. et al. - Seroepidemiology of human toxoplasmosis in Chile. Rev. Inst. Med. trop. S. Paulo, 38: 431-435, 1996.

11. DIALLO, S.; NDIR, O.; DIENG, Y. et al. - Seroprevalence de la toxoplasmose a Dakar (Senegal) en 1993; étude chez des femmes en periode de procreation. Cah. Santé, 6: $102-106.1996$.

12. DÍAZ-SUÁREZ, O.; PARRA, A.M. \& ARAUJO-FERNÁNDEZ, M. - Seroepidemiología de la toxoplasmosis en una comunidad marginal del Municipio Maracaibo, Estado Zulia, Venezuela. Invest. clin., 42: 107-121, 2001.

13. DÍAZ-SUÁREZ, O.; ESTÉVEZ, J.; GARCÍA, M.E. et al. - Seroepidemiología de la toxoplasmosis en una comunidad indígena Yucpa de la Sierra de Perijá, Estado Zulia, Venezuela. Rev. méd. Chile, 131: 1003-1010, 2003.

14. DURMAZ, R.; DURMAZ, B.; TAS, I. \& RAFIQ, M. - Seropositivity of toxoplasmosis among reproductive age women in Malatya, Turkey. J. Egyp. Soc. Parasit., 25: 693-698, 1995.

15. ETHEREDGE, G.D. \& FRENKEL, J.K. - Human Toxoplasma infection in Kuna and Embera children in the Bayano and San Blas, eastern Panamá. Amer. J. trop. Med. Hyg., 53: 448-457, 1995.

16. FIGALLO, L. \& MAEKELT, G.A. - Anticuerpos de toxoplasmosis en parturientas y recién nacidos de la maternidad "Concepción Palacios" de Caracas, Venezuela. Arch. venez. Med. trop. Parasit. Med., 4: 289-299, 1962.

17. FRENKEL, J.; LAZO, R. \& LAZO, J. - Encuesta sobre infección toxoplásmica en un grupo de alumnos del tercer año de medicina y en un número igual de gatos, de la ciudad de Guayaquil. Rev. Med. trop. Parasit., 1: 17-22, 1984.

18. FRENKEL, J.K. \& RUIZ, A. - Human toxoplasmosis and cat contact in Costa Rica. Amer. J. trop. Med. Hyg., 29: 1167-1180, 1981.

19. GARCÍA, J.L.; NAVARRO, I.T.; OGAWA, L.; DE OLIVEIRA, R.C. \& KOBILKA, E. - Soroprevalência, epidemiología e avaliação ocular da toxoplasmose humana na zona rural de Jaguapita (Paraná) Brasil. Rev. panamer. Salud. públ., 6: 157-163, 1999.

20. GUERINA, N.G.; HSU, H.W.; MEISSNER, H.C. et al. - Neonatal serologic screening and early treatment for congenital Toxoplasma gondii infection. New Engl. J. Med., 330: 1858-1863, 1994.
21. HEDMAN, K.; LAPPALAINEN, M.; SÉPPAIA, I. \& MAKELA, O. - Recent primary Toxoplasma infection indicated by a low avidity of specific IgG. J. infect. Dis., 159: 736-740, 1989

22. LIESENFELD, O.; PRESS, C.; MONTOYA, J.G. et al. - False positive results in immunoglobulin M (IgM) Toxoplasma antibody test and importance of confirmatory testing: the Platelia Toxo IgM test. J. clin. Microbiol., 35: 174-178, 1997.

23. MAEKELT, G.A. \& GÓMEZ, Z. - Primeras experiencias con la prueba de Sabin-Feldman para el diagnóstico de la toxoplasmosis. Arch. venez. Med. trop. Parasit. med., 4 $265-275,1962$.

24. MARTÍNEZ SÁNCHEZ, R.; MACHIN SÁNCHEZ, R.; SUAREZ HERNÁNDEZ, M. \& FACHADO CARVAJALES, A. - Aspectos seroepidemiológicos de la toxoplasmosis en 2 municipios de la provincia de Ciego de Ávila. Septiembre 1985. Rev. cuba. Med. trop., 41: 214-225, 1991

25. MITTAL, V.; BHATIA, R.; SINGH, V. \& SEHGAL, S. - Prevalence of toxoplasmosis in Indian women of child bearing age. Indian J. Path. Microbiol., 38: 143-145, 1995

26. NETO, E.C; ANELE, E.; RUBIM, R. et al. - High prevalence of congenital toxoplasmosis in Brazil estimated in a 3-year prospective neonatal screening study. Int. J. Epidem., 29: 941-947, 2000.

27. PUNDA-POLIC, V.; TONKIC, M. \& CAPKUN, V. - Prevalence of antibodies to Toxoplasma gondii in the female population of the Country of Split Dalmatia, Croatia. Europ. J. Epidem., 16: 875-877, 2000.

28. SCHENONE, H.; CONTRERAS, M.C.; SALINAS, P. et al. - Epidemiología de la toxoplasmosis en Chile. I. Prevalencia de la infección humana, estudiada mediante la reacción de hemaglutinación indirecta, en las tres primeras regiones. 1982-1985. Bol. chil. Parasit., 41: 36-39, 1987.

29. SERRANO, H. - Estudios sobre la incidencia de anticuerpos séricos para Toxoplasma en las poblaciones de Maracaibo y un pueblo rural del Estado Zulia y comparación de tres métodos serológicos distintos. Kasmera, 5: 75-101, 1974.

30. SOTO, U.R. \& TARAZÓN DE SOTO, S. - Toxoplasmosis y embarazo. Kasmera, 21(14): 1-36, 1993.

31. SOUSA, O.E.; SAENZ, R.E. \& FRENKEL, J.K. - Toxoplasmosis in Panama: a 10 years study. Amer. J. trop. Med. Hyg., 38: 315-322, 1988

32. TAKAHASHI, E. \& ROSSI, C. - IgM and IgA antibody responses in 12 cases of human acquired toxoplasmosis. Rev. Inst. Med. trop. S. Paulo, 39: 327-331, 1997.

33. VARGAS DE CAMINOS, N. - Títulos de anticuerpos para Toxoplasma en una población pediátrica de Maracaibo, Venezuela. Kasmera, 10: 72-81, 1982

34. VELASCO-CASTREJÓN, O.; SALVATIERRA-IZABA, B.; VALDESPINO, J.L. et al. Seroepidemiología de la toxoplasmosis en México. Salud. públ. Mex., 34: 222-229, 1992.

35. YIP, L.; McCLUSKEY, J. \& SINCLAIR, R. - Immunological aspects of pregnancy. Clin. Derm., 24: 84-87, 2006

Received: 22 February 2007

Accepted: 29 September 2008 